\title{
Legal extension of the impact bullying in school Madrasah Tsanawiyah (MTs) and Madrasah Aliyah (MA) Hj. Siti Julia Foundation Secanggang village Kabupaten Langkat
}

\author{
Fajar Khaifi Rizki ${ }^{*}$, D. Shahreiza ${ }^{1}$ \\ ${ }^{1}$ Faculty of Law, Universitas Sumatera Utara, Medan, Indonesia \\ *Email: fajarkhaifirizki89@gmail.com
}

\begin{abstract}
In general, the term Bullying is synonymous with acts of violence against children that occur at school. In other words, Bullying is defined as aggressive behavior carried out repeatedly by a person or group of students who have power over other students / students who are weaker with the aim of hurting that person. In Article 1 number 16 of Law Number 35 of 2014 concerning Amendment to Law Number 23 of 2002 concerning Protection of Children, violence is any act against a child which results in physical, psychological, sexual abuse and / or neglect, including threats to commit acts, coercion or deprivation of liberty unlawfully. Based on the provisions in the article above, it can be concluded that bullying is included in the form of violence against children. Considering bullying acts of violence against children, according to the Child Protection Act (UUPA) bullying is a criminal offense. Bullying can be subject to criminal sanctions in the form of imprisonment for a maximum of 3 (three) years 6 (six) months and / or a maximum fine of Rp. 72,000,000. On the other hand, BAL also has a civil aspect, namely the granting of rights to victims of violence (bullying) to demand material / in material compensation for perpetrators of violence. This is regulated in Article 71 D paragraph (1) jo Article 59 paragraph (2) letter i of the Law. 35/2014.
\end{abstract}

Keyword: Legal Aspects of Child Protection, Bullying Impact.

\begin{abstract}
Abstrak
Secara umum, istilah Bullying identik dengan tindakan kekerasan terhadap anak yang terjadi di sekolah. Dengan kata lain, Bullying di definisikan sebagai perilaku agresif yang dilakukan berulang-ulang oleh seseorang atau sekelompok siswa yang memiliki kekuasaan terhadap siswa/siswi lain yang lebih lemah dengan tujuan menyakiti orang tersebut. Di dalam Pasal 1 angka 16 Undang-Undang Nomor 35 Tahun 2014 tentang Perubahan Atas Undang-Undang Nomor 23 Tahun 2002 tentang Perlindungan Anak, kekerasan adalah setiap perbuatan terhadap anak yang berakibat timbulnya kesengsaraan atau penderitaan secara fisik, psikis, seksual, dan/atau penelantaran, termasuk ancaman untuk melakukan perbuatan, pemaksaan, atau perampasan kemerdekaan secara melawan hukum. Berdasarkan ketentuan dalam pasal diatas, maka dapat disimpulkan bahwa bullying termasuk dalam bentuk kekerasan terhadap anak. Mengingat bullying tindakan kekerasan terhadap anak maka menurut Undang-Undang Perlindungan Anak (UUPA) bullying adalah tindak pidana. Terhadap pelaku bullying dapat dikenakan sanksi pidana berupa penjara paling lama 3 (tiga) tahun 6 (enam) bulan dan/atau denda paling banyak Rp. 72.000.000,-. Di sisi lain UUPA juga memiliki aspek perdata yaitu diberikannya hak kepada anak korban kekerasan (bullying) untuk menuntut ganti rugi materil/inmateril terhadap pelaku kekerasan. Hal ini diatur dalam Pasal 71 D ayat (1) jo Pasal 59 ayat (2) huruf i UU. 35/2014.
\end{abstract}

Kata Kunci : Aspek Hukum Perlindungan Anak, Dampak Bullying.

\section{PENDAhULUAN}

Madrasah Tsanawiyah (MTs) dan Madrasah Aliyah Negeri (MA) merupakan sekolah madrasah dibawah kepengawasan Departemen Agama. Madrasah Tsanawiyah (MTs) adalah satuan pendidikan formal yang menyelenggarakan pendidikan umum dengan setara SMP kekhasan agama Islam yang terdiri dari 3 (tiga) tingkat pada jenjang pendidikan dasar sebagai lanjutan dari Sekolah 
Dasar, MI, atau bentuk lain yang sederajat, yang diakui sama atau setara Sekolah Dasar atau MI. Madrasah Aliyah (MA) adalah satuan pendidikan formal yang menyelenggarakan pendidikan umum dengan setara SMA kekhasan agama Islam pada jenjang pendidikan menengah sebagai lanjutan dari Sekolah Menengah Pertama, MTS, atau bentuk lain yang sederajat, diakui sama atau setara Sekolah Menengah Pertama atau SMP. (Khadijah Ummul Mu'minin, 2015, hal. 96 dan 155).

Maraknya pemberitaan di media massa terkait dengan tindak kekerasan terhadap anak di sekolah, nampaknya semakin melegitimasi tuduhan miring soal gagalnya sistem pendidikan di Indonesia. Kekerasan yang terjadi bukan hanya yang kasat mata bisa diamati seperti tawuran antar pelajar saja. Melainkan, ada bentuk kekerasan lain yang bersifat laten dengan dampak buruk yang jangka panjang namun terus terjadi secara terselubung, yakni bullying. Prinsipnya fenomena ini merujuk pada perilaku agresi berulang yang dilakukan seseorang atau kelompok terhadap pihak lain hingga mengakibatkan keadaan tidak nyaman bahkan terluka secara fisik maupun psikis (Prasetyo, 2011, hal. 20).

Berdasarkan hal tersebut di atas, bullying seolah-olah sudah menjadi bagian yang tak terpisahkan dari kehidupan anak-anak pelajar di zaman yang penuh persaingan ini. Kiranya, perlu dipikirkan mengenai resiko dan dampak yang akan dihadapi anak, agar selanjutnya dapat dicarikan jalan keluar untuk memutus mata rantai kekerasan yang saling berkelindan tanpa habis-habisnya. Tentunya, berbagai pihak turut bertanggung jawab atas kelangsungan hidup anak sebagai generasi penerus, karena anak-anak juga memiliki hak yang harus dipenuhi oleh negara, orang tua, guru, dan masyarakat. Oleh karena itu diperlukan komitmen bersama dan langkah nyata untuk mencegah mewabahnya praktik school bullying.

Pada dasarnya bullying dapat terjadi di lingkungan mana saja di mana ada interaksi sosial antar manusia berpotensi terjadi bullying didalamnya, antara lain di sekolah (school bullying), kampus, tempat kerja (work pleace bullying), dunia maya (cyber bullying), lingkungan politik (political bullying), lingkungan militer (military bullying), dan lingkungan masyarakat (preman, geng motor). Dalam hal ini, bullying di sekolah adalah kasus yang sering dilupakan. Padahal, bullying di sekolah dapat menyebabkan efek yang sangat serius baik dalam jangka pendek maupun jangka panjang bagi para korbannya.

Dalam jangka pendek bullying dapat menimbulkan perasaan tidak aman, takut pergi ke sekolah, merasa terisolasi, perasaan harga diri yang rendah, depresi atau bahkan menderita stress yang dapat berakhir dengan bunuh diri bagi si korban. Sedangkan dalam jangka panjang, korban bullying dapat menderita masalah gangguan emosional dan perilaku (Prasetyo, 2011, hal. 16).

Sekolah menjadi tempat yang efektif untuk melakukan tindakan bullying, karena sekolah merupakan ruang menimba ilmu bagi begitu banyaknya siswa dengan latar belakang dan jenjang pendidikan yang majemuk. Dalam kesehariannya, siswa intensif berinteraksi dengan teman sebaya yang kemudian berpotensi terjadi bullying diantara mereka. Terlebih di periode anak-anak yang memang belum mengerti tata pemilihan dalam bersikap. Tentu bullying bukanlah tujuan yang ingin dicapai dari proses pendidikan.

Keberhasilan seorang siswa cukup dipengaruhi oleh proses pembelajaran di sekolah, ketika lingkungan sekolah menjadi wabah praktik bullying, hal ini dikhawatirkan akan mengganggu perkembangan siswa baik secara psikis maupun fisik yang akan berdampak terhadap prestasi atau hasil belajar siswa. Sekolah yang menjadi cambuk terdepan menciptakan generasi penerus bangsa harus mulai berbenah guna dapat mencegah praktik bullying ini, mengingat berbagai dampak negatif yang diterima korbannya. Apalagi bullying terjadi kepada mereka para siswa dengan kategori usia yang sangat muda dan masih menerima semua apa yang dialami. Seperti halnya virus, bullying dapat menyerang siapa saja mereka yang memiliki daya tahan lemah. Apalagi terhadap anak-anak yang kestabilan berpikir mengenai perilaku yang baik dan buruk masih dalam proses pembentukan. Pada masa pertumbuhannya, anak jenjang usia 12-15 tahun yang tergolong sebagai remaja awal atau yang masih duduk di bangku Sekolah Madrasah Tsanawiyah (MTs) dan Madrasah Aliyah (MA), memiliki tingkat kematangan berpikir yang sangat labil dan mudah 
terpengaruh terhadap hal-hal negatif yang dapat menggangu proses sosialisasi di lingkungan sekolah maupun dalam kehidupan masyarakat.

Selain di rumah dan lingkungan sekitarnya, anak-anak cukup banyak menghabiskan waktu bersosialisasi di lingkungan sekolah, disanalah biasanya anak remaja cenderung untuk menunjukan jati dirinya masing-masing. Dalam hal ini, perilaku remaja yang terbentuk akan sangat dipengaruhi oleh keadaan lingkungan sosialnya, terutama teman sepermainan. Teman yang baik akan memberi pengaruh positif pada anak, tetapi sebaliknya teman yang kurang baik akan memberi pengaruh yang negatif. Sehingga di lingkungan sekolah inilah seharusnya dapat tercipta sebuah interaksi sehat yang dapat memberikan dampak positif terhadap perkembangan anak.

Melihat fenomena bullying seperti yang terjadi di sekolah tersebut, dalam sosiologi terdapat pendekatan teori yang dapat dilakukan untuk menganalisis fenomena ini, yaitu teori interaksionisme simbolik yang memberikan pokok perhatiannya kepada pemahaman tentang proses-proses interaksi sosial dan akibat-akibatnya bagi individu dan masyarakat. Interaksi adalah suatu proses dimana kemampuan untuk berpikir dikembangkan dan diungkapkan. Segala macam interaksi menyaring kemampuan kita untuk berpikir. Lebih dari itu, berpikir mempengaruhi seseorang dalam bertingkah laku. Dalam kebanyakan tingkah laku, seorang aktor harus memperhitungkan orang lain dan memutuskan bagaimana harus bertingkah laku supaya cocok dengan orang lain. Namun demikian tidak semua interaksi melibatkan proses berpikir, maka dapat dibedakan dua macam interaksi, yakni interaksi non-simbolik yang tidak melibatkan proses berpikir dan interaksi simbolik yang melibatkan proses berpikir (Ehan, 2005, hal. 9).

Atas dasar hal ini, menjadi penting untuk dilakukan sebuah pengabdian, mengingat begitu tingginya angka kekerasan atau bullying yang terjadi di sekolah di Indonesia dan berbagai dampak negatif yang dialami oleh para korbannya. Sekolah yang seharusnya menjadi tempat belajar, bermain yang nyaman dan aman bagi anak, justru menjadi momok menakutkan yang harus dihindari. Pendidikan yang diharapkan mampu menciptakan generasi penerus yang berbudi pekerti luhur dan bermanfaat bagi orang tua, bangsa dan Negara kini harus terkontaminasi oleh tindakantindakan pelaku bullying yang pastinya menimbulkan suatu sosial disorder atau kekacauan dalam sistem kehidupan masyarakat.

Bentuk pengabdian masyarakat yang dilakukan di Sekolah Madrasah Tsanawiyah (MTs) dan Madrasah Aliyah (MA) Yayasan Hj. Siti Julia yang ada di Desa Secanggang, Kabupaten Langkat. Pengabdian memilih lokasi tersebut karena sebagai sekolah yang mempunyai letak geografis jauh dari pusat kota, maka apa yang terjadi di sana jauh dari sentuhan kontrol sosial seperti ekspos media massa dan partisipasi masyarakat umum.

\section{METODE PELAKSANAAN}

Metode yang dipergunakan dalam kegiatan ini adalah dengan observasi, pemaparan, dan diskusi terarah yang diawali dengan pemaparan tentang penyuluhan dengan substansi hukum terhadap dampak bullying dan selanjutnya dilanjutkan dengan tanya jawab antara penyuluh dengan guru sekolah dan siswa-siswi, terutama untuk lebih memperjelas substansi penyuluhan. Melalui penyuluhan dan pemaparan dapat disampaikan materi-materi yang penting untuk diketahui oleh guru, siswa-siswi sekolah. Tanya jawab dapat melengkapi materi yang belum jelas dan diketahui oleh warga sekolah serta untuk memberikan masukan atas permasalahan yang dihadapi dalam pelaksanaan pengabdian ini.

\section{HASIL DAN PEMBAHASAN}

Dalam kegiatan ini para peserta penyuluhan atau siswa-siswi dapat memahami istilah dan pengertian bullying. Bullying adalah penggunaan kekerasan, ancaman, atau paksaan untuk menyalahgunakan atau mengintimidasi orang lain. Perilaku ini dapat menjadi suatu kebiasaan dan 
melibatkan ketidakseimbangan kekuasaan sosial atau fisik. Hal ini dapat mencakup pelecehan secara lisan atau ancaman, kekerasan fisik atau paksaan dan dapat diarahkan berulang kali terhadap korban tertentu, mungkin atas dasar ras, agama, gender, seksualitas, atau kemampuan. Tindakan penindasan terdiri atas empat jenis, yaitu secara emosional, fisik, verbal, dan cyber.

Budaya penindasan dapat berkembang di mana saja selagi terjadi interaksi antar manusia, dari mulai di sekolah, tempat kerja, rumah tangga, dan lingkungan.

Adapun bentuk-bentuk penindasan dalam bullying ini, antara lain:

1. Penindasan fisik

Tindakan penindasan dengan kontak secara fisik yang menimbulkan perasaan sakit fisik, luka, cedera, atau penderitaan fisik lainnya. Contohnya memukul, menampar, atau menendang orang lain.

2. Penindasan psikologis

Tindakan penindasan yang menimbulkan trauma psikologis, ketakutan, depresi, kecemasan, atau stres. selain itu juga menimbulkan kegalauan/gusar.

Menurut psikolog dari RS Pondok Indah, Jane Cindy Linardi, MPsi, Psikolog, ada karakter pelaku bullying yang bisa terlihat, terutama dari sisi emosionalnya. "Regulasi emosinya kurang, gampang marah, gampang tersinggung, susah mengontrol emosi," Selain itu, pelaku bullying biasanya memiliki perilaku agresif di mana jika merasa marah, maka seseorang itu bisa melakukan kekerasan fisik maupun verbal.

Disinilah bullying yang dilakukan seseorang bisa terlihat. Seorang pelaku bullying biasa bersifat cenderung ingin berkuasa dan mendominasi. Biasanya juga memiliki sifat kurang empati pada orang lain. "Konsep dirinya negatif, sehingga mencari kompensasi dengan tindakan bullying agar disegani,ditakuti," Jane menambahkan, pelaku bullying biasanya sudah terbiasa atau terpapar dengan kekerasan, baik di keluarganya maupun di lingkungan sekolah atau permainan.

Kemudian peserta penyuluhan atau siswa-siswi dapat memahami jenis-jenis bullying antara lain sebagai berikut:

1. Bullying fisik

Bullying fisik adalah bentuk intimidasi yang paling jelas, anak-anak tipe pembully secara fisik ini akan menggunakan tindakan fisik sebagai kekuatannya guna mengontrol korban mereka."Pengganggu secara fisik cenderung lebih besar, kuat, dan agresif daripada temannya yang lain. Contoh intimidasi fisik termasuk menendang, memukul, meninju, menampar, mendorong, dan serangan fisik lainnya".

Bullying fisik, termasuk yang paling mudah diidentifikasi. Selain itu, bullying fisik lebih banyak mendapat perhatian dari sekolah ketimbang jenis bullying lain.

2. Bullying verbal

Sesuai dengan namanya, pelaku bullying jenis ini menggunakan kata-kata, pernyataan, dan memanggil nama dengan cara hang kurang pantas untuk mengintimidasi korban. Pelaku bullying verbal umumnya akan menghina tanpa henti untuk meremehkan, merendahkan, dan melukai orang lain. Pelaku memilih target berdasarkan cara mereka melihat, bertindak, atau berperilaku. Pelaku bullying verbal umumnya menargetkan anak-anak dengan kebutuhan khusus. Bullying verbal ini sering sangat sulit diidentifikasi karena serangannya hampir selalu terjadi ketika orang dewasa tidak ada. Selain itu, banyak orang dewasa merasa bahwa hal-hal yang dikatakan anak-anak tidak berdampak signifikan pada orang lain.

"Akibatnya, mereka biasanya memberi tahu korban untuk mengabaikannya. Padahal, intimidasi verbal harus ditanggapi dengan serius". Penelitian telah menunjukkan bahwa intimidasi verbal dan pemanggilan nama yang tidak pantas memiliki konsekuensi serius dan dapat meninggalkan bekas luka emosional yang dalam.

3. Agresi relasional

Agresi relasional ini merupakan tipe bullying yang berbahaya. Orang tua dan guru seringkali tidak memperhatikannya. Bully jenis ini terkadang disebut dengan bully 
emosional. Agresi relasional erat dengan tindakan manipulasi, di mana remaja mencoba menyakiti temannya atau menyabotase status sosial mereka. Pembully jenis ini sering mengasingkan orang lain dari suatu kelompok, menyebarkan desas-desus, memanipulasi situasi, dan merusak kepercayaan. Tujuan di balik pelaku intimidasi yang agresif adalah meningkatkan kedudukan sosial mereka sendiri dengan mengendalikan atau mengintimidasi orang lain.

"Secara umum, anak perempuan cenderung sering melakukan agresi relasional ketimbang anak laki-laki. Akibatnya, anak perempuan yang terlibat dalam agresi relasional sering disebut gadis nakal atau frenemies". Korban agresi relasional kemungkinan akan diejek, dihina, diabaikan, dikucilkan dan diintimidasi. Agresi relasional ini umum terjadi di sekolah menengah, tapi tidak terbatas pada remaja.

4. Cyberbullying

Ketika seorang remaja menggunakan internet, smartphone, atau teknologi lainnya untuk melecehkan, mengancam, mempermalukan, atau menargetkan orang lain, ini disebut cyberbullying. Jika orang dewasa terlibat dalam pelecehan ini disebut pelecehan cyber atau cyberstalking. Contoh cyberbullying termasuk memposting gambar yang menyakitkan, membuat ancaman online, dan mengirim email atau teks yang menyakitkan. Cyberbullying berkembang di kalangan anak muda.

Pelaku cyberbullying seringnya mengatakan hal-hal yang mereka tidak berani katakan secara langsung. Teknologi membuat mereka merasa anonim, terisolasi dan cenderung lebih aman.

5. Penindasan seksual

Penindasan seksual terdiri dari tindakan berulang, berbahaya, dan memalukan yang menargetkan seseorang secara seksual. Contohnya, pemanggilan nama dengan hal-hal yang berbau seksual, komentar kasar, gerakan vulgar, sentuhan, proposisi seksual, dan materi pornografi. Contohnya, pelaku bully berkomentar kasar tentang penampilan, daya tarik, perkembangan seksual, atau aktivitas seksual seorang gadis. Dalam kasus-kasus ekstrem, intimidasi seksual membuka pintu bagi serangan seksual.

"Anak perempuan sering menjadi sasaran intimidasi seksual baik oleh anak laki-laki maupun anak perempuan lainnya. Anak laki-laki mungkin menyentuhnya dengan lancang, dan membuat komentar kasar tentang tubuh mereka. Sedangkan jika pelakunya perempuan, mungkin memanggil dengan kalimat yang tak pantas serta menghina penampilan atau tubuh si korban". Sexting juga dapat menyebabkan bullying secara seksual. Sebab, bukan tak mungkin konten yang diberikan pada seseorang disebarkan ke orang lain karena satu dan lain hal.

6. Bullying Prasangka

Jenis penindasan ini dapat mencakup semua jenis penindasan lain, termasuk penindasan di dunia maya, verbal, relasional, fisik, sampai seksual. Ketika intimidasi terjadi, anak-anak menargetkan orang lain yang berbeda dari mereka dan memilihnya.

Seringkali, jenis intimidasi ini parah dan dapat membuka pintu untuk membenci kejahatan. Kapan pun seorang anak diganggu karena orientasi seksual, ras, atau agamanya, itu harus dilaporkan. Psikolog anak dan keluarga Anna Surti Ariani, mengatakan banyak faktor yang membuat anak membully. Misalnya saja di usia sekolah dasar, anak mulai mencari identitas. Salah satunya dengan berteman atau kumpul-kumpul bersama kelompok tertentu.

"Hanya saja, untuk bisa masuk ke dalam kelompok tersebut, terkadang seluruh anggota menetapkan persyaratan tertentu. Tak jarang persyaratan ini terdengar aneh, semisal harus memakai baju yang sama atau identitas lainnya. Kalau tidak sama, tidak dianggap di dalam kelompok". 
Kemudian ciri pelaku bullying, pelaku bullying tidak mengenal usia dan jenis kelamin. Beberapa ciri-ciri pelaku bullyingyang mungkin dapat terlihat adalah seperti:

a. Memiliki keinginan untuk mengendalikan orang lain;

b. Fokus pada diri sendiri;

c. Memiliki keterampilan sosial yang buruk dan sulit untuk bergaul;

d. Kurang empati;

e. Sering merasa tidak aman dan membuat dirinya nyaman dengan cara menggretak atau mengganggu orang lain;

f. Kesulitan untuk memahami emosi seperti rasa bersalah, empati, belas kasih, dan penyesalan.

Pelaku bullying dapat dikenali dari ciri-ciri di atas. Meskipun begitu, pelaku bullying juga kemungkinan memiliki karakter yang berbeda. Terdapat pelaku bullying yang melakukan bullying secara terang-terangan, sebagian lagi mungkin memilih untuk bersikap ramah di depan, namun menusuk dari belakang.

Kemudian siswa-siswi memahami dampak bullying, dimana dampak-dampak bullying dapat mengancam setiap pihak yang terlibat, baik anak-anak yang di bully, anak-anak yang mem-bully, anak-anak yang menyaksikan bullying, bahkan sekolah dengan isu bullying secara keseluruhan.

Bullying dapat membawa pengaruh buruk terhadap kesehatan fisik maupun mental anak. Pada kasus yang berat, bullying dapat menjadi pemicu tindakan yang fatal, seperti bunuh diri. Adapun dampak-dampak bullying, antara lain:

1) Dampak Negatif

Anak-anak yang menjadi korban bullying lebih berisiko mengalami berbagai masalah kesehatan, baik secara fisik maupun mental. Adapun masalah yang lebih mungkin diderita anak-anak yang menjadi korban bullying, antara lain:

a. Munculnya berbagai masalah mental seperti depresi, kegelisahan dan masalah tidur, masalah ini mungkin akan terbawa hingga dewasa;

b. Keluhan kesehatan fisik, seperti sakit kepala, sakit perut dan ketegangan otot;

c. Rasa tidak aman saat berada di lingkungan sekolah;

d. Penurunan semangat belajar dan prestasi akademis.

Dalam kasus yang cukup langka, anak-anak korban bullying mungkin akan menunjukkan sifat kekerasan.

2) Dampak Positif

Di samping dampak negatifnya, bullying juga dapat mendorong munculnya berbagai perkembangan positif bagi anak-anak yang menjadi korban bullying. Anak-anak korban bullying cenderung akan:

a. Lebih kuat dan tegar dalam menghadapi suatu masalah;

b. Termotivasi untuk menunjukkan potensi mereka agar tidak lagi direndahkan;

c. Terdorong untuk berintrospeksi diri.

3) Dampak pada Pelaku Bullying

Pelaku bullying itu sendiri juga bisa mendapatkan dampak negatifnya ketika dewasa. Saat dewasa, pelaku rentan terjebak kecanduan narkoba, terlibat dalam tindak kekerasan, dan tindak kriminal lainnya. Bahkan ia bisa bersikap abusif atau melakukan tindak kekerasan pada orang terdekatnya, seperti pada pasangan atau anak-anaknya di masa yang akan datang.

4) Dampak pada Orang-Orang yang Menyaksikan Bullying

Pihak yang menyaksikan tindak bullying juga bisa mendapat dampak negatifnya. Pada usia sekolah, mereka mungkin akan sering bolos atau tidak masuk sekolah. Mereka bisa berisiko mengalami kecanduan alkohol dan narkoba. Gangguan kesehatan mental seperti depresi dan kecemasan juga bisa mereka alami. 
Fajar Khaifi Rizki et.al Legal Extension of the Impact Bullying

Anak-anak yang jadi korban bullying berisiko melakukan tindak bunuh diri. Namun, penyebab seseorang memiliki keinginan bunuh diri bisa jadi tak hanya disebabkan oleh bullying. Banyak isu lainnya yang bisa memengaruhi niat seseorang untuk bunuh diri, seperti depresi, masalah di rumah, dan riwayat trauma. Apalagi bila korban tak mendapat dukungan dari orangtua, teman sebaya, atau sekolah, keinginan untuk bunuh diri bisa meningkat.

Dampak psikologis bullying khususnya pada korban tak bisa disepelekan begitu saja. Saat luka fisik sembuh, trauma yang dirasakan bisa jadi akan menghantui seumur hidup. Kemudian cara mengatasi bullying, bullying adalah masalah serius yang perlu diatasi karena dapat memberikan dampak jangka panjang baik untuk korban dan juga pelaku. Berikut adalah beberapa langkah yang bisa dilakukan untuk mengatasi bullying:

1. Ceritakan pada orang dewasa yang dapat dipercaya. Ceritakan pada orang tua maupun guru yang memiliki otoritas untuk menindaklanjuti perilaku bullying.

2. Abaikan penindas dan jauhi. Seperti yang disebutkan sebelumnya, penindas akan merasa senang apabila mendapatkan reaksi seperti yang dia inginkan.

3. Tingkatkan keberanian dan rasa percaya diri. Tunjukkan pada lingkungan sekitar bahwa Anda bukan orang yang lemah dan mudah untuk ditindas.

4. Bicara pada pelaku bullying. Tunjukkan bahwa apa yang dilakukan pelaku bukan hal yang baik dan bahkan berbahaya.

5. Bantu teman yang menjadi korban bullying. Jika menyaksikan perilaku bullying, jangan diam saja dan cobalah untuk memberi dukungan pada korban.

Berikut dalam sesi tanya jawab peserta siswa-siswi menanyakan kepada penyuluh sebagai berikut:

1) Bagaimana sanksi hukum terhadap orang yang melakukan bullying?

Jawab: Sanksi hukumnya adalah tertuang didalam peraturan perundang-undangan Negara Republik Indonesia yaitu "Setiap orang dengan sengaja dan tanpa hak mendistribusikan dan/atau mentransmisikan dan/atau membuat dapat diaksesnya informasi elektronik dan/atau dokumen elektronik yang memiliki muatan penghinaan dan/atau pencemaran nama baik dapat dipidana dengan pidana penjara paling lama 6 (enam) tahun dan/atau garing denda paling banyak Rp. 1.000.000.000,- (satu miliar rupiah)". (Pasal 27 UU ITE).

"Setiap orang dengan sengaja dan tanpa hak mengirimkan informasi elektronik dan/atau dokumen elektronik yang berisi ancaman kekerasan atau menakut-nakuti yang ditujukan secara pribadi". (Pasal 29 UU ITE).

"Barang siapa sengaja menyerang kehormatan atau nama baik seseorang dengan degan menuduhkan sesuatu hal, yang maksudnya terang supaya hal itu diketahui umum, diancam karena pencemaran dengan pidana penjara paling lama sembilan bulan atau pidana denda paling banyak empat ribu lima ratus rupiah". (Pasal 310 ayat 1 KUHPidana).

"Jika hal itu dilakukan dengan tulisan atau gambaran yang disiarkan, dipertunjukkan atau ditempelkan di muka umum, maka diancam karena pencemaran tertulis dengan pidana penjara paling lama satu tahun empat bulan atau pidana denda paling banyak empat ribu lima ratus rupiah". (Pasal 310 ayat 2 KUHPidana).

"Tidak merupakan pencemaran atau pencemaran tertulis, jika perbuatan jelas dilakukan demi kepentingan umum atau karena terpaksa untuk membela diri". (Pasal 310 ayat 3 KUHPidana).

2) Apabila ada teman yang melakukan bullying apakah boleh kita membalasnya dengan melawan dengan kekerasan?

Jawab: Tidak boleh, karena itu tidak menyelesaikan masalah malah akan menimbulkan masalah yang baru dikemudian hari. Selain itu dikarenakan negara kita menjunjung tinggi asas dan penegakan hukum nasional yang berlaku di Negara Republik Indonesia dari sabang sampai marauke. 


\section{KESIMPULAN}

Berdasarkan hasil kegiatan pengabdian ini, maka kami dapat menarik kesimpulan sebagai berikut:

1. Bullying adalah suatu perlakuan yang sangat tidak pantas untuk dilakukan oleh seseorang kepada suatu kelompok dan kepada orang lainnya. Dikarenakan dampak yang ditimbulkan dari bullying tersebut sangatlah merugikan fisik dan mental orang yang menerimanya bahkan si pelaku sendiri.

2. Selain menimbulkan kerugian terhadap dampak fisik dan mental, pelaku bullying juga dapat diancam dengan peraturan perundang-undangan yang berlaku di Negara Republik Indonesia baik secara aspek hukum perdata, hukum pidana dan UUITE.

\section{UCAPAN TERIMAKASIH}

Artikel ini merupakan salah satu hasil dari Program Pengabdian kepada Masyarakat yang Dibiayai oleh dana NON PNBP Universitas Sumatera Utara Sesuai dengan Surat Perjanjian Penugasan Pelaksanaan Pengabdian kepada Masyarakat Program Mono Tahun Dosen Muda Tahun Anggaran 2019. Oleh karena itu, diucapkan terima kasih kepada Rektor Universitas Sumatera Utara atas dukungan dana dan fasilitas yang diberikan. Terima kasih juga kepada Mitra pada kegiatan pengabdian ini.

\section{DAFTAR PUSTAKA}

Ehan. 2005. Bullying Dalam Dunia Pendidikan, Fakultas Psikologi UI.

Khadijah Ummul Mu'minin. 2015. Nazharat Fi isyraqi Fajril Islam. Wikipedia.

Prasetyo. (2011). Bullying di Sekolah dan dampaknya bagi masa depan anak, Jurnal Pendidikan Islam.

Undang-Undang Nomor 73 Tahun 1958 tentang Kitab Undang-Undang Hukum Pidana (KUHPidana)

Undang-Undang Nomor 35 Tahun 2014 tentang Perubahan Atas Undang-Undang Nomor 23 Tahun 2002 tentang Perlindungan Anak (UUPA)

Undang-Undang Nomor 11 Tahun 2008 tentang Informasi dan Transaksi Elektronik (UU ITE)

Peraturan Menteri Pendidikan dan Kebudayaan Nomor 82 Tahun 2015 tentang Pencegahan dan Penanggulangan Tindak Kekerasan Pada Satuan Pendidikan

Peraturan Menteri Pendidikan dan Kebudayaan Nomor 18 Tahun 2016 tentang Pengenalan Lingkungan Sekolah Bagi Siswa Baru 